\title{
Toplu Ulaşım Sosyolojisinin Temel Boyutları: Literatür İncelemesi ve Alan Gözlemleri
}

\author{
DOI: $10.26466 /$ opus.933443
}

\begin{abstract}
$*$
* Arş. Gör., AHBV Üniversitesi, İletişim Fakültesi, Ankara/Türkiye

E-Posta: ayse.mirza@hbv.edu.tr

ORCID: 0000-0003-0668-993X

** Prof. Dr., AHBV Üniversitesi, İletişim Fakültesi, Ankara/Türkiye

E- Posta: himmet.hulur@hbv.edu.tr

ORCID: $\underline{0000-0002-5863-4976}$ Öz

Ulaşım sosyolojisi kavramı stnırları muğlak ve geniş bir kavramdır. Bu alanda üretilmiş çalışmalar genellikle ulaşım araçlarının yapı ve özelliklerine; şehiriçi ulaşım politikalarına; ulaşım alanındaki sorunlar ve çözüm önerilerine odaklanmaktadır. Ulaşım ile ilgili araştırmalar genellikle üniversitelerin Mimarlık fakültelerine ve Şehir ve Bölge Planlama bölümüne mensup araştırmacilarca incelendiği için bu disiplinlerle sınırl kalmaktadır. Bu makalenin amacı, toplu ulaşım alanımın insan ilişkileriyle iloili yönüne dair görece az sayıdaki çalı̧manın bir incelemesini yapmak ve ulaşım araçlarında insan davranışını ve etkileşimini şekillendiren ögelere eğilen çalışmalar hakknda bir literatür özeti sunarak bu alanın önemini vurgulamaktır. Bu nedenle bu makale kapsaminda ele alınan tüm çalışmalar betimleyici analiz ile ele alınmıştır. Bunun yaninda Ankara'daki toplu taşıma araçlarında katılıml gözlem tekniğiyle üç yılı aşkm bir zaman kapsayan alan araştırması yapılmıs ve buradan elde edilen bilgiler literatür incelemesi ile sentezlenmiştir. Yapılan literatür incelemesi sonucunda, bu alanda oldukça değerli araştırmalar yapılmış olsa da hala daha çeşitli ve derinlemesine analizlere ihtiyaç duyulduğu görülmüştür.
\end{abstract}

Anahtar Kelimeler: Ulaşım Sosyolojisi, Toplu Taşıma Araçları, Toplumsal Etkileşim. 


\title{
The Main Dimensions of Public Transport Sociology: Literature Review and Field Observations
}

\begin{abstract}
The concept of sociology of transportation is a wide and ambiguous concept. Studies produced in this field generally focus on the structure and characteristics of transportation vehicles, urban transportation policies, problems and solutions in the field of transportation. Research on transportation is generally limited to these disciplines as it is examined by researchers from the Architecture faculties of universities and the Department of City and Regional Planning. The purpose of this article is to underline the importance of this field by providing a review of the relatively few studies on the human relations aspect of the public transport space and by providing a literature summary on studies that address the elements that shape human behavior and interaction in transport. Therefore, all studies within the scope of this article are handled with descriptive analysis. In addition, a field study covering a period of more than three years has been carried out in public transportation vehicles in Ankara with the participatory observation technique, and the information obtained here has been synthesized with a literature review. As a result of the literature review, it was seen that although quite valuable research has been done in this area, there is still a need for more diverse and in-depth analysis.
\end{abstract}

Key Words: The Sociology Of Transportation, Public Transport, Social Interaction. 


\section{Giriş}

Toplu ulaşım araçları gündelik yaşamın önemli bir ögesidir. Özel araç sahipliği sunduğu konfor nedeniyle her geçen gün artış göstermesine karşın, günümüzde toplumun büyük çoğunluğu ulaşım ihtiyacını karşılamak için toplu taşıma araçlarını kullanmaktadır. Gezici bir mekân özelliği bulunan toplu taşıma araçları toplumun farklı kesimlerinden kişilerin karşılaşması ve etkileşime girmesi için de önemli bir alan sunmaktadır. Bu nedenle de toplumsal yaşamdan kopuk olmadığını dile getirmek isteyen kişiler genellikle toplu taşıma araçlarını kullandıklarını ifade etme gereği duyarlar. Her ne kadar toplumların gelişmişlik seviyeleri toplu taşımayı kullanan toplumsal kesimlerin genişliğini ve toplu taşımanın koşullarına etki etse de, bu mekânlarda bir araya gelen kişilerin genel olarak oldukça heterojen bir topluluk oluşturduğu söylenebilir. Her yaş grubundan, neredeyse her meslekten ve toplumsal gruptan bireyler kısa ya da uzun süreli yolculuklarda bir araya gelir, deneyim yoluyla elde ettikleri bilgileri kullanarak bir yolculuk performansı sergilerler.

Toplu taşıma araçlarının özel, kamusal ya da yarı-kamusal alanlar olup olmadıkları tartışılabilir olsa da birbirini tanımayan kişiler için önemli bir karşılaşma, iletişim ve etkileşim ortamı sundukları gerçeği inkâr edilemez. Bu ulaşım araçlarındaki etkileşim ve iletişim çok farklı kuramsal bakış açılarıyla incelenebilir, ancak söz konusu etkileşimler ulaşım araçlarında gerçekleştiği için ulaşım sosyolojisi böyle bir incelemenin en temel çerçevelerinden biri olarak kabul edilebilir. Ulaşım sosyolojisinin insan iletişim ve etkileşimine eğilen Türkçe literatür incelendiğinde, bu alanda büyük bir boşluk olduğu görülmektedir. Bunun yanında dünyadaki literatürün de oldukça parçalı, birbirinden kopuk olduğu ve gelişkin bir içeriğe sahip olmadığı ortaya çıkmaktadır. Bu nedenle bu makalede öncelikle ulaşım sosyolojisinin insan ilişki ve davranışına etki eden yönlerine ağırlık veren temel kaynakların bir incelemesini yapmak amaçlanmıştır. İlgili literatürün nasıl gelişme gösterdiğinin anlaşılması için yapılan çalışmalar eskiden yeniye tarih sırasına göre incelenmeye çalışılmıştır. Ulaşım sosyolojisi alanının gelişmesine katkıda bulunan başlıca çalışmalar dikkate alınmış olmakla birlikte bu alanın temel çerçevesini belirleyen öncü çalışmalara daha fazla yer ayrılmıştır. 
Bunun yanında bu makale kent içi ulaşımın etkileşim ve iletişim boyutuyla ilgili yürütülmekte olan bir doktora tezinin bir parçasıdır. İlgili tez için üç yılı aşkındır şehir içi hizmet veren otobüslerde katılımlı gözlemler yürütülmüş ve bu deneyimlerin bir kısmı literatür özeti yapılan makalelerle harmanlanmıştır. Böylece Ankara'daki toplu taşıma araçlarındaki insani ilişkilere dair gözlemsel verilere dayalı olarak Türkiye' de ulaşımın sosyolojik boyutları hakkında sınırlı bir perspektif ve bir kesit sunulmaya çalışılmaktadır. Toplu ulaşımın yapısal unsurları her ne kadar yolcuların konforlarına ve dolayısıyla davranış ve iletişim biçimlerine etki etse de bu makalenin konusunu oluşturmadığı için kapsama dâhil edilmemiştir.

\section{Ulaşım Sosyolojisinde İnsan İlişkilerine Dair Öncü Çalışmalar}

Ulaşım sosyolojisi hakkında yapılan ilk çalışmalardan biri Morris Davis ve Sol Levine'in kaleme aldıkları "Toward a Sociology of Public Transit" (Toplu Taşıma Sosyolojisine Doğru) (1967) adlı çalışmadır. Yazarlar, modern endüstriyel toplumlarda toplu taşımanın bireylerin yaşamında oldukça fazla yer almasına rağmen, bu konuda yeterince çalışma olmadığını ve ayrıca bu konunun yerleştirileceği hazır bir teorik çerçevenin de bulunmadığını söylerler. Sosyolojinin de bu alana yeterince kılavuzluk etmediğini belirten yazarlar, bunun nedenleri olarak; otobüs gibi toplu taşıma araçlarındaki insanların sosyal gruplar gibi görülmemesini, bu kişilerin birbirleriyle yerleşik ilişkilerinin olmamasını ve bireylerin davranışlarının sosyal statülerince belirlenmemesini neden gösterirler (Davis ve Levine, 1967, s.84-85). Fakat ilerleyen yıllarda görüleceği gibi, ulaşım araçlarındaki insan ilişkilerine, isminden da anlaşılabileceği gibi ulaşım sosyolojisi odaklanmış, sosyal psikoloji ve eğitim alanlarından da konuya ilgi gösterilmiştir.

Davis ve Levine (1967, s.85) sosyolojik analize daha yatkın olmasından ötürü, okyanus seferleri ya da tren gezileri gibi yolculukların daha önce bir takım çalışmalara konu olduklarını, kendilerinin ise mola vermeyen kısa mesafeli yolculuklar ile şehir içi ulaşım araçlarını merkeze aldıklarını belirtirler. Bu araçlarda, daha önce belirtildiği gibi kişilerin birbirleriyle kalıcı sosyal ilişkileri olmasa da bu ilişkilerin oluşma potansiyel mevcuttur. Özellikle tekrarlayan yolculuklar diğer yolcularla ya da 
taşıma personeliyle anlamlı ilişkiler geliştirmek için imkân sağlayabilir. Bunun yanında belirli koşullar ve uyaranlarla sıradan bir yolcu toplulu$\breve{g} u$ aktif bir kalabalığa dönüşebilir. Toplu taşıma araçlarında yapılacak dikkatli gözlemler bize Davis ve Levine'in haklılı̆̆ını gösterebilir. İşe veya okula gitmek için her gün aynı saatlerde otobüse binen kişiler arasinda genellikle bir göz aşinalığı oluşur. Bu kişiler herhangi bir sebep olmaksızın birbirleriyle muhabbet edebilecekleri gibi, otobüs içerisinde gerçekleşen olaylara karşı -otobüsün kalabalığı, şoförün otobüsü hızlı ya da kuralsız kullanması vb.- kendi aralarında dayanışma göstererek ya da yolcular arasında doğacak tartışmalarda aldıkları tavırlarla aralarında bir takım bağlar oluşabilir. Bu ilişkilerin tohumları bazen otobüse binmeden, henüz duraktayken de atılabilir. Nitekim bu çalışma kapsamında yapılan gözlemler, yolcuların geçmiş yıllara göre günümüzde sosyal konular hakkındaki konuşmalarını, otobüs içinden daha çok duraklarda gerçekleştirdiklerini göstermiştir. Bunun bir nedeni, durakta daha az kişinin bulunması dolayısıyla insanların duraklarda daha rahat iletişim kurabilmesi iken; bir diğer neden de son yıllarda münferit olayların her an her yerde anında kayıt altına alınıp sosyal medyada gözler önüne serilmesinin sıra dışı davranış sergileyen veya görece muhalif bireyleri suskunlaştırabilmesidir. Nitekim bu ortamlarda çekilen bu tip videolar birtakım soruşturmalara konu olmasıyla bireylerin yaşamında olumsuz sonuçlara yol açabilmekte ve geri dönülmez etkiler bırakabilmektedir. Fakat bu durumun farklı şehirler ve şehir içindeki münferit bölgeler için değişiklikler gösterebileceği gerçeği de gözden kaçırılmamalıdır.

Şehir içi toplu ulaşım araçlarında belirli davranışlar sergilemeyi engelleyen güven eksikliğinin bir diğer nedeni de otobüse binen kişilerin, daha önce de belirtildiği gibi, bir topluluk oluşturmamasıdır. Doob (1952), ortak bir hedef için, aralarında bir bağlantı olmadığı halde bir araya gelen kalabalıkları "birlikte hareket eden grup" olarak tanımlamıştır. Bu gruptaki kişiler birbirinin farkında olan ve aynı hedefi arayan kişilerdir, ancak aralarında herhangi bir rekabet ya da işbirliği yoktur. Grup üyeleri aynı kültüre ve aynı sosyal sınıfa mensup olsalar da, davranışlarını düzenleyen ortak bir resmi organizasyona sahip değillerdir. Olası temasları kültürel olarak belirlenmiştir ancak bu durum aralarında bir temas olmasını gerektirmez. Böylesi gruplara örnek olarak durakta otobüs bekleyen ya da yazılı bir sınava girecek olan kişiler verilebilir. 
Nitekim bu örneklerde de olduğu gibi, bu kişiler birbirleriyle değil, kendileriyle meşguldürler (Doob, 1952' den akt. Davis ve Levine, 1967, s.86).

Davis ve Levine (1967, s.86) otobüs bekleyen ya da otobüste seyahat eden kişilerin rekabet etmedikleri ve işbirliği yapmadıkları görüşünün yanıltıcı olabileceğini; sadece kendisiyle ilgili görünen bir kişinin bile çevresinden birkaç kişiyi dikkate aldığını belirtirler. Toplu taşıma araçsaldır ve yolcular bir an önce inmek için bu araçlara binerler. Fakat yolcular iniş-biniş sırasında sıkıntı yaşamamak için bir takım lojistik problemleri önceden tahmin etmelidirler. İniş kapısına yakın olmayan yolcular inmeleri gereken durağı kaçırarak zamansal açıdan önemli problemlerle karşılaşabilirler, bu nedenle inmeleri gereken duraktan önce, yavaş yavaş kapılara yanaşmaya çalışırlar ya da kalabalık bir metro platformunda inenlere öncelik veren yolcular, kendileri vagona adım atamadan metronun kalkış yapmasıyla dışarıda kalabilirler. Dolayısıyla toplu taşıma araçları birçok stratejik taktik geliştirmeyi zorunlu hale getirir (Davis ve Levine, 1967, s.86-87). Yolcuların siraya girmedikleri, birden fazla hattın geçtiği otobüs duraklarında da aynı problem vardır. Yoğun iş saatlerinde yolcular otobüse binebilmek için kapılara koşturup birbirlerinin önüne geçmeye, kendilerinin önüne geçmeye çalışan kişileri çeşitli taktiklerle (dirsekleriyle) engellemeye çalışırlar. Bir başka strateji -her ne kadar yasak olsa da, özel halk otobüslerinin fazla yolcu alma isteğinden ötürü uygulanmayan- orta ve arka kapılardan otobüse giriş yapmaya çalışmaktır. Bu durumda da hiz önemlidir, zira sizden önce davranan biri otobüse binebilirken, siz yeterince hızlı hareket etmediğiniz için otobüsün dışında kalabilirsiniz. Otobüse dair geliştirilen taktikler sadece biniş ve inişle sınırlı değildir. Otobüste oturabilecek, düşmeden, sendelemeden ayakta durabilecek yer bulmak ya da olası bir tacizi önlemek amacıyla kişilerin aklından bir anda sayısız düşünceler geçebilir. Özellikle kadınlar otobüslerde sıkça karşılaşılan taciz vb. durumlardan kendilerini sakınmak için daha fazla strateji geliştirmek zorunda kalırlar. Örneğin koridor kısmında oturmaktansa cam kenarını tercih ederler, kadınların daha yoğun olduğu yerlerde durmaya çalışırlar ya da daha rahat bir savunma geliştirebilmek için ayaktayken de cam kenarında yakın, başka kişilerle temas etme olasılıklarının daha az olduğu yerlere geçerler.

Davis ve Levine $(1967$, s.88) toplu taşımanın yolcuların yapacakları şeyleri oldukça kısıtladığını, özellikle yolculuk süresinin kısa olduğu 
durumlarda edimlerin daha da azaldığını ve çoğunlukla otobüsün içerisinde diğer yolculara çok yakından veya açık bir şekilde bakmaları pek mümkün olmadığından dışarıyı seyrettiklerini söylerler. Dışarıyı seyretmenin yanında otobüslerde kitap okuma, müzik dinleme ve günümüzde telefonla uğraşma seçenekleri de mevcuttur. Ayrıca akıllı telefonlar kitap okuma, oyun oynama, müzik dinleme, arkadaşlarla sosyalleşme gibi birçok fonksiyonu bünyesinde barındırdığı için yolcular otobüste genellikle bu araçla meşgul gözükürler. Fakat bu çalışma için yapılan gözlemler, otobüsün doluluk oranına göre yapılan aktivitenin de değişebildiğini göstermiştir. Otobüs kalabalık olduğunda insanlar kendilerini diğer kişilerden izole etmek amaciyla daha çok telefon ve diğer alternatiflerle uğraşırken; otobüs daha tenha olduğunda dışarıyı izlemenin daha fazla olduğu gözlenmiştir. Burada Goffman'ın otobüs gibi alanlarda dişarıyı izlemenin bir oyalanma seçeneğinden çok, bir alan genişletme fonksiyonu olduğu iddiası yerinde görünmektedir (1971/2016, s.54). Otobüsün zorunlu olarak içinde yer alınan dar bir alan olmasından ötürü bireylerin kendilerini kısıtlanmış hissetmeleri ve dolayısıyla alanlarını genişletmek istemeleri doğaldır. Bunun yanında diğer insanlarla olan göz temasının da oldukça rahatsız edici olması, dışarının daha güvenli ve ilgi çekici bir alan sunmasını sağlar. Akıp geçen görüntüler kişiyi hem içeride hem dışarıda hissettirir. Bu tip durumlarla ilişkili olarak Davis and Levine (1967, s.88-89) toplu taşımadaki yolcuları, hiç oyun oynanmayan bir tiyatrodaki izleyicilere benzetirler. Boş bir salonda görülecek ve duyulacak kayda değer bir şey olmadığında insanlar perdenin rengine ve spot 1şıklarının yerleştirilmesine gözünü diker veya basılı bir programa bakarlar. Küçük kümelere ulaşmışlarsa, ikili ve üçlü konuşmalara girebilirler, böylece beklemek daha çekilir hale gelebilir. Fakat böylesi bir ortamda dahi, mekânın kısıtlayıcı etkileri ve gürültü gibi faktörler insanların yapabileceklerini sinırlar.

Davis ve Levine'in savı otobüsün çok kalabalık olmadığı, sakin zamanlar için doğrudur. Öte yandan kalabalığın artığı durumlarda otobüste sürekli bir hareketlilik vardır. Daha önce de bahsedildiği gibi bireyler kalabalık toplu taşıma araçlarında sürekli bir taktik peşindedir; daha sakin, daha güvenli bir alana geçmek; daha düzgün tutunulabilecek bir yeri ya da cam kenarını kovalamak gibi. Bunun yanında bu taktiksel durumlar kişilerarası iletişim durumlarının da doğmasına neden olur: 
sizi iteleyerek başka bir yere geçmek isteyen kişilere, oturacağınız yere sizden önce davranan birine ya da size fazla yakın duran birine tepki göstermek veya rahatsız edici bir takım durumlar karşısında dayanışma göstermek bunlar arasında sayılabilir.

Davis ve Levine (1967, s.89) toplu taşımanın güzergah kısıtlılı̆̆1 ve ortamdan çıkış eksenli olmasından ötürü "mono-enstrümantal" bir karakteri olduğunu söylerler. Yazarlar bu durumun onun olumsuz yanı olan, etkileşim kalıplarındaki potansiyel tersliklerle, yani yolcuların sardalye gibi istiflenmesi, yolculuğun yavaş, kirli yapısı ve bir takım suç unsurlarının varlığıyla güçlendiğini belirtirler. Aynı zamanda durağı kaçırma, rahatsız edici birinin yanınıza oturması, otobüs şoförünün kabalığı, yükleri olan hamile bir kadının başınızda beklemesi, bir grup okul çocuğunun araca binip yüksek sesle konuşması gibi bir takım olumsuz faktörlerin de yolculuğu çekilmez hale getirebileceğini eklerler. Bu olumsuz faktörlerin bir kısmı eleştirilebileceği gibi, pek çok yeni faktör de eklenebilir.

Davis ve Levine $(1967$, s.90) çalışmalarının ABD ve Batı Avrupa'yı kapsayan planlanmamış bir dizi gözlemden oluştuğunu ve oldukça ihmal edilmiş bu alanda karşılaştırmalı, kültürlerarası ve daha sistematik ve farklı yaklaşımların bir arada kullanılacağı çalışmalara ihtiyaç olduğunu belirtirler. Bu alana oldukça katkıda bulunmuş yazarların bu sözleri günümüzde hala geçerliliğini korumakta ve yazının ileri aşamalarında görülebileceği gibi, başka kuramcılar tarafından da dile getirilmektedir.

Toplu taşımanın kent sakinleri üzerine etkilerini inceleyen öncü çalışmalardan biri de Bateman ve Brown'in (1968) Guidelines for New Systems of Urban Transportation (Yeni Kentsel Ulaşım Sistemleri Rehberi) adlı kitaptaki "Urban Planning, Transport and Human Behavioral Science" (Şehir Planlama, Ulaşım ve İnsan Davranışı Bilimi) bölümündeki yazılarıdır. Yazarlar bu çalışmada şehir plancıları ile davranış bilimleri arasındaki sınırlı diyaloğu aşmayı; onları yeni düşünmelere teşvik etmeyi; temel insan menfaatlerini korumak için hangi koşulların oluşturulması ve sürdürülmesi gerektiğine yönelik yardım sunmayı ve bu doğrultuda bazı öneri ve sorular yöneltmeyi hedeflerler. Bunu da on dokuz davranış bilimcisini $^{1}$ bir araya getirip münazara etmelerini sağlayarak gerçekleş-

\footnotetext{
${ }^{1}$ Panelistler papaz, sosyal çalışmacı, avukat, ekonomist, antropolog, sosyal psikolog, sosyolog, psikolog, tarihçi, felsefeci ve psikiyatristlerden oluşmaktadır (Bknz: Bateman ve Brown, 1968, s.39-41).
} 
tirmeye çalışırlar (Bateman ve Brown, 1968, s.1-2). Yazarlar çalışmada şehir plancılarına yardımcı olmak için, yani onların toplumun gereksinimlerini daha iyi anlayabilmeleri için, dört temel başlıkta temel insani özellikleri ele almışlardır.

Başlıklardan ilki "İnsan Organizasyonunun Farklı Düzeylerinin Benzerlikleri"dir. Buna göre "bireyin, grubun, örgütün, 'toplumun' sosyal veya kültürel ihtiyaçlarının ve 'sağlığının' birbirinden bağımsız olarak gerçekçi bir şekilde değerlendirilebileceği düşüncesinden vazgeçilmesi gerekmektedir" (Bateman ve Brown, 1968, s.3). Bir yandan toplumsal iyileşme için bireyden yola çıkmalı ve onun gereksinimleri anlaşılmalıdir. Öte yandan birey kendi kendine yeten bir biyolojik sisteme sahip değildir. Başka bir deyişle beslenme, barınma gibi bir takım fiziksel ihtiyaçların yanı sıra sosyal ihtiyaçları da olan, kişilerarası iletişimini "sağlıklı" bir şekilde kurması yani "normal" bir psikolojiyi sürdürmesi gereken bir canlı formudur (Bateman ve Brown, 1968, s.3-5). Özetle sağlıklı bir toplumsal yapının var olabilmesi için, sosyal bir varlık olan bireyin temel insani gereksinimleri karşılanmalıdır. Şehir planlayıcıları, kişilerarası iletişimin olumlu bir çerçevede işleyebilmesi için bireyleri temel almalıdırlar.

Böyle bir durumun varlığı da bizi "normal bireylerin bazı temel ruh sağlığı ihtiyaçları" adlı ikinci başlığa taşır. Bireylerin akıl sağlığı için gerekli olan başlıca bileşenler temel güven duygusu, özerk irade duygusu, inisiyatif duygusu ve öz kimlik duygusu olarak siralanabilirken; ikincil bileşenler de ortak bir kimlik duygusu, liderlerle ve kişisel ideallerle özdeşleşme olarak adlandırılabilir. Bireyler bu duygularını kişilerarası ilişkiler ve nesnelerle olan ilişkilerinde kurdukları gibi, yine bu ilişkilerde meydana gelecek önemli değişikliklerle bu duyguları kaybedilebilir. Psikolojik olarak "normal" tanımlanan bir kişi, bu ilişkilerde meydana gelecek bozulmalar sonrası, "sapkın" hale gelebilir. Bu "sapkın" davranışın düzelmesi için temel ihtiyaçların karşılanması konusundaki güven duygusunun yeniden sağlanması gereklidir (Bateman ve Brown, 1968, s.6-7).

Bateman ve Brown'ın panelistleri normal kişilik ve akıl sağlığının temel bileşenlerinin geliştirilmesi ve sürdürülmesinde kentsel biçim, ulaşım ve planlamanın rolünü sorgulamışlardır. Bu noktada akılda tutulması gereken en önemli faktör, bireylerin duygusal sağlık ve normal 
kişiliğinin bir kez kurulup güven altına alınan nitelikte olmamasıdır. Bireyler hayatta kalmak için birbirine bağımlı, yaşamsal ihtiyaçları olan ve bunlara erişememenin çeşitli deformasyonlar yarattığ ${ }_{1}$ canlılardır. "Kentsel biçim ve ulaşım, kaynakların ve uyaranların erişilebilirliğinin doğasındaki temel belirleyiciler olduğundan, bunların iyileştirilmesi için planlama yapmanın otomatik olarak son derece arzu edilen ve güvenilir bir çaba olarak nitelendirildiği görülmektedir." Fakat panelistler kentsel biçim ve ulaşımın yurttaşların çıkarlarını gözeterek yapılmadığını, nüfus yapısı ve yoğunluğu gibi faktörlerin dikkate alınmamasının yanı sıra farklı etnik kesimleri barındıran gettolar gibi bölgelerin kendilerine ait farklı bir takım problemler taşıdığını da aktarmışlardır (Bateman ve Brown, 1968, s.7-10).

Otobüs kullanımının bireylerin psikolojisi üzerinde bir etkisi olup olmadığı ya da bir nasıl bir etki yarattığ farklı kesimlerden kişilerle yapılacak görüşmelerle anlaşılabilir. Fakat otobüslerin yoğun olarak kullanıldığ 1 saatlerde yapılacak bir yolculuk bunun olumlu bir etkiden ziyade oldukça stres yaratan bir deneyim olduğunu açıça gösterebilir. Otobüsün kalabalıklığı ve diğer yolcularla herhangi bir fiziksel/sosyal mesafenin olmaması stres oluşumu için başlı başına yeterli bir faktör iken; bir de bu kalabalığın yarattığı havasız ortam ve gürültü gibi diğer unsurlar da otobüsle yapılacak bir yolculuğu oldukça zorlayıcı bir süreç haline getirebilir. Bunun yanında otobüse binen kişiler genel olarak benzer sosyo-ekonomik kesimlerden geliyor gibi gözükse de (ne de olsa hepsi otobüs kullanıyor), özel araç sahipliği ve kullanımı ülkelerin kalkınmışlık seviyesine göre biçimleneceğinden, otobüslere binen kişiler arasındaki sınıfsal konumlanma geniş bir skalayı kapsayabilir. Bu konu, şehrin fark11 yerlerinde ikamet eden kişilerle yapılacak görüşmelerle daha çok netlik kazanacaktır. Fakat bu makaleye kaynaklık eden tez çalışması için şu ana kadar yapılan -sınırlı- gözlemler böyle bir ayrımın olduğu yönündedir. Bateman ve Brown'ın yukarıda aktarılan bireysel akıl sağlığı için gerekli gördükleri temel ihtiyaçlara her bireyin erişimi yoktur. Otobüs içerisindeki insani koşulların sağlanması bir yana; toplumda otobüse erişim için gerekli ücreti sağladığı halde, dış görünüşünün yaydığı izlenim nedeniyle otobüse alınmayan kişiler de mevcuttur. Bunun yanında engelli kişilerin toplu taşıma araçlarına erişiminde de pek çok problem vardır. En 
azından engelli kişilerin toplu taşıma araçlarındaki yokluğu, bu alanda ciddi problemlerin varlığını düşündürmektedir.

Bateman ve Brown (1968, s.17-18) "İnsan İletişiminin Bazı Tuhaf Boyutları" başlıklı kısımda genel olarak kişilerarası iletişim kurallarına değinmektedirler. Burada hem kişilerin kendi öznel geçmişleri, bilgi birikimleri, yani iletişim sırasındaki kodlama ve kod açımı süreci önemlidir, hem de geribildirimler, yani mesajın kod açımı ile diğer kişilere verilecek tepkinin niteliği önemlidir. İletişim sürecini karmaşıklaştıran, insanların hayata dair farklı ard alanlarının olmasıdır. Bireylerin içine doğdukları aile, yetiştikleri çevrenin kültürel ve sınıfsal yapısı gibi dışsal faktörler ile bireyin bilgi birikimi, psikolojisi, kişilik yapısı gibi özellikler kişilerarasında farklılıklara, dolayısıyla kişilerarası iletişim yapısında farklılıklara sebep olacaktır. Bu nedenle otobüs gibi kamusal alanlarda karşılaşılan kişilere karşı daha temkinli yaklaşılır. Bu tip alanları kullanımın seçime bağlı olmaması, yani kişisel tercihlerle katılım imkânının bulunmaması, bireyleri daha önce kendi kişisel çevrelerinde olmayan bir takım kişi ve gruplarla bir araya getirir. Buralardaki kişilerin tahmin edilemezliği, bilinmezliği bazı kişileri, daha önce de belirtildiği gibi, daha temkinli olmaya yöneltirken, bazı kişiler de herhangi bir bireysel çerçevelemeye girmeden diledikleri gibi davranabilirler. İşte tam da en az bir kişinin kişilerarası mesafelere aldırmadığı bu tip ilişkilenmelerde, bir takım iletişim aksaklıkları meydana gelmekte ve iletişimdeki bu yanlış anlamalar bazen farklı şiddet biçimlerine de varabilen sorunlar doğurmaktadir.

Bateman ve Brown (1968, s.24-27) kentsel planlayıcılar için davranış bilimlerine dair yukarıda özetlenmeye çalışılan bir giriş yaptıktan sonra kent planlayıcıları ve insan yönetimi için bir takım başlıklar altında eleştiriler ve önerilerde bulunurlar. "Müşteri ve Müşteri Sistemleri" başlı̆̆1 altında, kent planlayıcılarının işverenlerinin talepleri doğrultusunda hareket ederken, yolcular gibi, hizmet alacak kesimlerin ihtiyaçlarını yeterince dikkate almadıklarını belirtirler. Fakat başarılı bir planlama ancak bu süreç içerisinde yapılacak çeşitli müzakereler sonucu elde edilebilir.

"Toplum görüşü" adlı başlıkta panelistlerin de görüşlerine başvurularak, coğrafi yayılım, şehre yakınlık ve şehrin sunduğu imkânlar gibi, toplu taşıma açısından dikkate alınması gereken unsurlara değinilir. 
Şehir merkezine uzak bölgelerde oturan ve çeşitli etkinlikler için merkeze inen kişilere dönüş imkânı sağlanması gerektiği gibi, planlayıcı unsurların üzerinde durulur (Bateman ve Brown: 1968, s.28).

"Özerklik ve bağımlılık" başlığında toplu taşıma araçlarındaki çağdaş sosyal normların insanları ne denli kısıtladığına değinilir. Örneğin gece kıyafetiyle metroya binmenin yadırganması gibi normlar karşısında toplu taşıma kullanıcılarına ne gibi başka imkânlar sunulabileceği, hangi ekonomik ve teknolojik faktörlerin kullanıcıların ulaşım seçeneklerini kontrol etme veya başkasının kontrolüne bağımlı olma seçeneğini belirlediği gibi birtakım sorular sorulur (Bateman ve Brown: 1968, s.36).

"Sosyal Çevre" başlığında, toplu taşımada sabah 7'de işe giden kişilerle, maç müsabakasına giden bir grubun karşılaşmasının gruplar arasında yüksek bir gerilime yol açacağına ve bu gibi durumları incelemek için ulaşım ekolojisinin incelenmesi gerektiğine işaret edilir. Böyle bir araştırma için insanların ulaşım sırasında ne zaman ve ne kadar izolasyona ihtiyaç duyduklarının belirlenmesi gerektiğini söyleyen yazarlar, taşıma araçlarının statü ve fiyatının yüksekliğinin kişilerin mahremiyet düzeyini belirlemesinin yanında, grupların homojenliğine de etki ettiğini belirtirler (Bateman ve Brown: 1968, s.36). Bunun yanında yoksulluk ulaşım araçlarında sadece izolasyon ve mahremiyete etki etmemekte, ulaşım araçlarına erişimdeki ekonomik ve fiziksel yetersizliklerin, yoksulların birden fazla topluluğa üyeliklerini sürdürememelerine de neden olmaktadır. Bu nedenle ulaşım sistemlerinin kamu kuruluşları dişında "sahiplik" yapılarının olup olmaması önemlidir (Bateman ve Brown: 1968, s.36-37). Daha önce de değinildiği gibi, eğer akşam saatlerinde şehirde bir etkinliğe katılacak kişi, dönüş için toplu ulaşımı kullanamıyorsa, taksiyle dönmek zorundaysa bu etkinliğe katılımdan ekonomik sebeplerle mahrum kalmaktadır. Dahası otobüse binecek kadar parası olmayan bir kişi, kendi ikamet ettiği yerden uzakta bulunan ücretsiz bir etkinliğe ya da kendini geliştireceği bir eğitim kursuna dahi gidemeyebilir.

Söz konusu sebeplerle kentsel alanları planlayanlar, ulaştırma sistemlerinin tasarımında sürekli olarak şehrin yerleşim değişimini ve dönüşümünü göz önüne almalı, birtakım esnemelerin nüfus üzerindeki etkilerini belirlemek için araştırmalar yapmalıdır (Bateman ve Brown: 1968, s.36-37). Bateman ve Brown'un 1968'de önerdiği, yolcuların yaşamlarını 
kolaylaştıracak birçok iyileşme günümüzde sağlanmış durumdadır. Örneğin yazarlar trenin gecikme nedenini yolcuların bilmek isteyeceğini (yapılan anonslar), yolcuların geribildirimlerde bulunarak ulaşım sisteminin işlerliğinin artabileceğini (mavi masa vs.), ulaşım sistemi için bilgi ağlarının tasarımına (ego cepte) ihtiyaç duyulduğunu, tiyatro ve sinema biletlerinin metro alanlarında satılabileceğini (gişeler) ifade ederler. Bunun yanında ve her zaman ihtiyaç duyulan bir diğer faktör "ulaşım sisteminin tasarımı kamu politikasının ve toplumsal hedeflerin ifade edilmesi için bir araç olarak görülmelidir." Çünkü gündelik yaşamda büyük yer tutan ulaşım sistemleri insan çıkarlarını oldukça ilgilendirmektedir (Bateman ve Brown: 1968, s.38-39). Yazarların da sıkça belirttiği gibi, sağlıklı bir toplumun yolu sağlıklı bireylerden geçmekte ve sağlığın önemli bir bileşeni de bireylerin ruhsal dengelerini korumalarıyla sağlanabilmektedir.

Glenn Yago (1983, s.171) ise "The Sociology of Transportation" (Ulaşım Sosyolojisi) adlı çalışmasında kentleşme ve ulaşım arasındaki bağlantıyı, insan ilişkilerini de içerecek şekilde irdelemektedir. Yago'ya (1983, s.171) göre ulaşım, toplum ve yer/mekân arasındaki ilişkiyi merkezi olarak etkilemektedir. Şöyle ki, ulaşımdaki değişiklikler kentsel ve bölgesel alandaki insani faaliyetlerin organizasyonunu etkilediği gibi, çevreyi yapılandırır, kentsel büyümeyi teşvik eder, şehirlerarası ilişkileri düzenler. Nitekim artık şehirlerin merkezleri ile merkezi ilçeleri arasındaki ulaşım süresi bir saati bulabilmekte, hatta bu süreyi aşabilmektedir. Fakat şehir içi ulaşım araçlarının elverişliliğinin artması gibi faktörler, şehrin çeperinde olan uydu kentler gibi alanlara yönelik nüfus artışını çoğaltabilmektedir. Bu bölgeler zaman içerisinde yeni sosyal oluşumlarla hem kendi kendine yeter hale gelmekte hem de merkeze ulaşılabilirliğin kolaylığı, bireylerin kentte ikamet etme algılarını koruyabilmelerine imkân sağlamaktadır. Toplu konut reklamlarında da söylendiği gibi, uydu şehirler artık "şehre bir nefes kadar yakın"dır. Fakat şehir içi ulaşım araçlarının bireylerin hayatını ne derece kolaylaştırdığı tartışılabilir bir konudur. Yukarıda bahsedilen, "şehrin dışında şehrin içindeymiş gibi olma hissi" daha çok özel araç sahiplerine özgü bir rahatlıktır. Yago'nun (1983, s.171-172) da belirttiği gibi farklı kesimlerden kişilerin ulaşım araçlarına ulaşımı konusunda bir eşitlik söz konusu değildir. Yapılan araştırmalarda "kentsel yoksullar arasında yerleşim yeri ve is- 
tihdam olanakları ile genç, yaşlı, engelli, ırksal ve etnik azınlıklar ve kadınların sosyal izolasyonu arasındaki eşitsizliklerin sosyal etkisine dikkat çekilmiştir."

1970-1980 yılları arasında sosyal psikologların yaptığı araştırmalarda ulaşımın aile ve toplumdaki bireysel sosyal etkileşimi nasıl etkilediği incelenmiştir. Bu dönemde, ayrıca, deneysel çalışmalar, saha çalışmaları ve zaman-bütçe analizleri yapılmış, bu çalışmalar ulaşımın gündelik yaşam üzerindeki etkilerinin derinliğini göstermişlerdir. Bir başka çalışma grubu ise ulaşım teknolojisini şekillendiren kurumsal güçlere odaklanmıştır. Bu grup çalışmalarını kentsel tarih, politika örgütlerinin çalışmaları ve kentsel politik ekonomiye odaklanan araştırmalara dayandırmış ve böylece daha önceki ulaşım çalışmalarındaki teorik boşluklar doldurulmuştur. "Bunun yanında bu çalışmalar, yerel transit işletim sistemlerinin tarihsel işlemlerini, ulaştırma endüstrisinin endüstriyel organizasyonunun bu alandaki politikayı nasıl etkilediğini ve ulusal ve yerel ulaştırma politikası oluşturma çalışmalarını içermiştir" (Yago, 1983, s.172).

Ekonomik gelişmeler ve ticari firmaların konumlanması, nüfusun yayılımını etkileyen faktörlerdir ve bu faktörlerde meydana gelen değişiklikler ulaşımın şekillenmesinde de rol oynar. Bunun yanında ulaşım alanındaki değişimler, kentin gelişimine ve yayılımına etki etmektedir. Bu bağlamda "kent-ekolojik bakış açısı, ulaşım teknolojisinin kentsel büyüme üzerindeki doğrudan etkisine odaklanmaktadır" (Yago, 1983, s.172173).

Kesitsel araştırmalar ise şehirlerarası ulaşım hizmetlerinin farklılıklarını açıklamaya çalışmıştır. Kent ekolojik bakış açısının ulaşım teknolojilerini merkeze alan, nedensel bakış açısını tersine çeviren kesitsel araştırmalarda, ekolojik yapılanmaların ulaşım hizmetlerinin genişliği ve karışımını belirlediği yönünde bir argümanı savunulmuştur. "Kentlerin fiziksel özellikleri (yaş, büyüklük, nüfus yoğunluğu) onların, hem bireylerin seçimleri hem de bunları yansıtan politikalar yoluyla 'en uygun' ulaşım çözümlerine yatkın hale getirilmesine neden olmuştur" (Yago, 1983, s.173). Ulaşım politikalarında en etkili olan birincil faktör nüfus büyüklüğüdür. Nüfusun büyüklüğü ulaşım hizmetleri için pazar ölçeğinin yaklaşık değerini belirlerken; nüfus yoğunluğu da işletme ekonomisine etki eder. Bunların yanında şehrin yaşının büyüklüğü, toplu taşıma- 
ya erişim ve toplu taşımanın verimliliği için olumlu bir etkendir, çünkü bu şehirler fiziksel yapılarının daha oturmuş olmasının yanında, yerleşim biçimleri açısından daha yoğundurlar (Yago, 1983, s.173). Yago'nun da belirttiği gibi kentleşmenin eski bir tarihe dayanması, hem şehirlerin gelişmişliğine etki ettiği için ulaşım koşullarını etkilemekte hem de bu şehirlerin yöneticilerinin bu konuda daha çok bilgi birikimine sahip olmasını sağlamaktadır. Fakat Yago (1983, s.175) kentsel büyümenin zamanlaması ve kentteki ulaşım sistemi arasında bir ilişki olsa da bunun ulaşım teknolojilerinin uygulanmasındaki geniş çeşitliliği açıklayamad1ğını, politikanın da bu alanda etkili bir faktör olduğunu belirtir. Aslında Yago'nun da yer yer ima ettiği gibi ulaşım politikalarını etkileyen birbiriyle ilintili pek çok unsur vardır. Tüm bu faktörler ve onların ulaşım politikalarına etkisi, en nihayetinde bireylere ve gündelik yaşama sirayet etmektedir.

Yago (1983, s.184-185) ulaşım ile gündelik yaşam arasındaki ilişkiye dair yapılan çalışmaların üstünkörü olduğunu, bu çalışmalarda sadece sosyal psikolojik yöne değinildiğini ve dolayısıyla aile ve toplumsal etkileşime yönelik yorumların spekülatif kaldığını belirtir. 1983 yılına kadar yapılan çalışmaların bir özetini sunan Yago, ilk olarak Brunner'a değinir. Brunner 1966 yılındaki çalışmasında "çevrenin bir parçası ve bu çevre ile birey arasındaki önemli bir aracı olarak kentsel ulaşımın, kullanıcılarının özerklik ve kontrol arzuların etkileyebildiğini ve bundan etkilenebildiğini" belirtmiştir (akt. Yago, 1983, s.185). Bu nedenle şehirdeki yolcular bu arzulara hizmet eden ulaşım sistemlerini tercih etmişlerdir. Korte ve Grant'ın 1980 yılındaki çalışmalarında ulaşım ile ilişkili stres yaşayan deneklerin istenmeyen (yardım eksikliği) veya uygunsuz (saldırganlık) davranışlarda bulundukları gözlenmiştir (akt. Yago, 1983, s.185). Daha çok yayaların davranışlarına yoğunlaşan Korte ve Grant (1980, s.417418), çalışmalarında ayrıca trafikteki gürültünün artmasıyla yayaların çevresel farkındalığının azaldığını; bunun yayaların daha hızlı yürümelerine yol açtı̆̆ını bulmuşlar ve bu verilerin anlık çevresel faktörlerin insanların sosyal davranışını etkilediğini kanıtladığını belirtmişlerdir.

Ulf Lundberg (1976, s.26-27) ise "Urban Commuting: Crowdedness And Catecholamine Excretion" (Kentte İşe Gidiş-Geliş: Kalabalık ve Katekolamin Salgı) başlıklı çalışmasında büyük şehirlerde yaşayıp, banliyölerde oturan ve her gün şehrin merkezindeki işlerine gitmek için trenler- 
de uzun zaman harcayan bireylerin yolculuklarına odaklanmış ve gündelik yaşamda pek çok stres faktörüyle boğuşan insanların, bu yolculuklardan nasıl etkilediğini araştırmıştır. Yakın zamanda meslektaşlarıyla birlikte yaptıkları bir araştırmaya referans veren Lundberg², bu çalışmada işe gidip gelirken, düzenli olarak trenlerde zaman harcayan kişilerden, bir yolculukları sonrası idrar örneği alarak, adrenalin düzeylerini ölçtüklerini ve daha kalabalık şartlarda yolculuk edenlerin adrenalin düzeylerinin daha yüksek çıktığını belirtmiştir. Mevcut çalışmasında ise 1974 yılında İsveç'te gerçekleşen petrol krizinin etkisiyle, çalışanların karneyle işe gidip gelmelerinden faydalanarak, kalabalık faktörünü kontrol edebilmesi sayesinde, önceki çalışmasına katılan deneklerden yeniden idrar örneği alarak bir karşılaştırma yapmış, ayrıca deneklerden trenlerdeki koşulların nicel tahminlerini yapmasını istemiştir.

Lundberg'in (1976, s.30-31) tren seyahatlerinde yaşanan stresin, en azından belirli limitler dâhilinde, seyahatin uzunluğuna ya da süresine bağlı olmaktan çok trenin koşullarına bağlı olduğu ortaya koymuştur. Örneğin yolcuların, koltuk ya da firma seçme gibi, trenin koşulları üzerinde herhangi bir kontrole sahip olması, stresin azalmasında etkili olmuştur. Bunun yanında, her zaman yeterli bir koşul olmasa da mekânsal kısıtlamanın kalabalık stresini tetiklediği görülmüştür. Algılanan kalabalık, farklı koşullar altında farklı değişkenlerin yoğunluğuna göre değişebilmiştir. Fakat yine de daha önce psikolojik ölçme teknikleri konusunda çok az deneyime sahip olan kişilerin öznel niceliksel tahminlerinin güvenilir olduğu bulunmuştur. Ayrıca yolcu sayısının artması ve boş koltukların azalmasının etkisi, deneklerin seyahat durumların kontrol edebilme imkânlarının azaldığını hissetmelerine neden olmuştur. Lundberg'in çalışmasında da görüldüğü gibi, kontrol duygusu seyahat stresinde önemli bir faktör olarak öne çıkmıştır. Dolayısıyla özellikle mesai saatlerinde otobüse binebilmek ya da temel sosyal mesafeyi korumak bile güçken; otobüslerde yaşanan kalabalık herhangi bir kontrol hissiyatına izin vermemektedir.

\footnotetext{
${ }^{2}$ Ayrıntılı Bilgi için Bknz: Singer. J.E.. U. Lundberg, and M. Frankenhaeuser. (1978) "Stress on the Train: A Study of Urban Commuting." Baum, A., Singer, J.E., Valins, S. (Eds.), Advances in Environmental Psychology. The Urban Environment, 1, 345-361
} 
Yago'nun da daha önce belirttiği gibi (1983, s.185-186) kentsel ulaş1mın sosyal psikolojik boyutları üzerine yapılan araştırmalar kısıtlı çerçevelere sahip olsa da; kentsel alanların bölünme şeklinin işyerinin toplumsal yaşamdan izolasyonuna, yaşlıların ve gençlerin görünmezliğine ve mahallelerde sosyal uyumun erozyonuna yol açtığı görülmüştür. Bunun yanında motorize bir hale gelme ve hatalı ulaşım politikaları kentsel deneyim çeşitliliğini daraltmakta, toplulukları ve işyerlerini ayırarak, şehirli yolcuları iş ve ev arasındaki dünyadan yalıtmaktadır.

\section{Toplu Ulaşım Alanındaki Etkileşim Pratiklerine Dair Güncel Çalışma- lar}

Andrei Balan (2011, s.1878-1881) ise "Symbolic Relations in Public Transport" (Toplu Taşımada Simgesel İlişkiler) adlı çalışmasında Mark Ague'den yola çıkarak, kasıtlı kişilerarası ilişkilerin olmadığı, geçici yerlerdeki ya da yok-yerlerdeki ${ }^{3}$ bireyler arasındaki ilişkilerin doğasını araştırmaya çalıştığını söyler. Bu nedenle toplu taşıma araçlarında gerçekleşen gündelik kişisel etkileşimlerin psikolojik ve sembolik bir yorumunu sunmaya çalışır. Bunu da Bükreş'teki toplu taşıma araçlarını en iyi temsil ettiğini söylediği metro ve tramvaydaki etkileşimler ve sözel olmayan davranışları inceleyerek gerçekleştirmeye çalışır. İncelenen kategoriler ise şunlardır: demografik özellikler, şehrin farklı bölgelerine seyahat eden kişiler arasındaki farklılaşmalar, prososyal ve antisosyal davranışların ortaya çıkışı, yabancılar arasındaki sosyal etkileşimin nedenleri, özel statüye sahip kişilere (bilet müfettişi, güvenlik personeli vb.) karşı tutum ve davranışlar, izlenim yönetimi ve kişisel alanın yönetimi.

Balan'ın (2011, s.1880-1881) bulgularına göre toplu taşıma araçlarındaki konumlanma yaşa ve toplumsal statüye göre değişmektedir. Gençler ve mavi yakalı kişiler toplu taşıma araçlarının arka kısımlarını; yaşlılar ön kısımları; beyaz yakalı ve entelektüel kişiler ise orta kısımları tercih etmişlerdir. Metroda ve bekleme platformlarında acelesi olan kişiler çıkışa yakın yerlerde konumlanmıştır. Bunun yanında metroda kişisel

\footnotetext{
3 Mark Ague (1992: 74) mekan ve yer arasında bir ayrıma gidip buradan yok-yerler kavramına ulaşır. Ona göre yer, kimlikleyici, ilişkisel ve tarihselken; mekan ve yok yerler bu özellikleri taşımaz. Yerler aşina olunan, insanların çeşitli ilişkiler geliştirdiği mahalle kahveleri gibi alanlarken; yok-yerler sosyal ve sembolik ilişkilerin olmadığı, otobüs, tren gibi transit alanlar, alışveriş merkezleri gibi alanlardır.
} 
mesafenin yakınlığının tramvaya göre daha tolere edilebilir olduğu gözlenmiş ve bunun nedeni olarak mimari kapanma algısının kişisel alan beklentisini bilinçsiz bir şekilde azalttığ düşünülmüştür.

Balan'a (2011, s.1881) göre tramvaya biletsiz biniş imkânının varlığı ve bilet denetçilerinin olmaması, tramvaylarda metroya kıyasla insan çeşitliliğinin artmasına neden olmaktadır. Bu çeşitliliği sağlayan gruplardan biri "varış noktası olmayan gezginler", yani zaman geçirmek için tramvaya binen ya da tramvayı sığınak gibi kullanan insanlardır. Bunun yanında, tramvayda yapılan gözlemler, prososyal davranışların aracın ön ve orta kısımlarında daha sık görüldüğ̈̈nü, yaşlıların ve fiziksel kısıtları olan kişilerin ön kısımlarda oturma tercihinde bu faktörün de rol oynayabileceğini göstermiştir.

Tramvaylarda yapılan gözlemler sürücü kabininin çevresindeki kişilerin daha kısık sesle konuştuklarını; arka kısımda oturan kişilerin ise ön kısımdakilere oranla daha yüksek sesle ve daha canlı bir şekilde sohbet ettiklerini ortaya çıkarmıştır. Daha önce bahsedilen demografik ve sosyal faktörlerin yanında bu durumu izah edici yeterince verinin olmadığını söyleyen Balan, bu gerçeğin tramvay sürücüsünün işlevsel otoritesince sağlandığını varsaydıklarını söyler. Ona göre kabin alanındaki sürücünün yolculardan daha yüksek olarak konumlanması, şoförün simgesel otoritesine katkıda bulunur. Bu nedenle sürücünün gayriresmi liderliğini ve otoritesini kabul eden, çoğunluğu yaşlılardan oluşan yolcular, şoförün koruyucu liderliğini kabul eder ve ona yakın yerlere oturmaya çal1şırlar. Bu durumda yaşlıların kendilerini dışarıdan gelecek tehlikelere karşı daha savunmasız hissetmeleri rol oynar. Şoförün simgesel otoritesinin zayıfladığı otobüsün arka kısımlarında ise marjinal bireyler ya da dilenciler gibi sosyal normlara karşı çıkan kişiler daha yoğun olarak öbeklenir. Bu nedenle otobüsün bu kısımlarında daha çok olay çıkar. Burada konumlanan diğer yolcular da ön taraftakilere kıyasla, suçlu ya da toplumdan dişlanmış kişilerden daha fazla uzaklaşmaya çalışırlar (Balan, 2011, s.1882). Tramvaylarda sürücülerin otoritesi her ne kadar hissedilir olsa da, esasında şoförlerin tramvayın sosyal yaşamına katılımları çok düşüktür. Hatta sürücüler kabinlerinin iç kısmını kendi kişisel yaşam ve değerlerini de yansıtacak bir takım objelerle kaplayarak kendilerini tramvayın geri kalanından izole etmeye çalışırlar (Balan, 2011, s.1882). 
Öte yandan halk otobüslerinde sosyal kontrolü inceleyen Connor ve Tewksbury (2012, s.5-8) otobüslerde şoförlerin sosyal kontrolün en belirgin aracı olduğunu söylerler. Yazarlar, kapı bekçisi olarak adlandırdıklar1 şoförlerin ilk olarak otobüse binmeyi kontrol eden kişi olduğunu ve yeterli parası olmayanları, geçiş süresi dolmuş biletlerle otobüse binmeye çalışanları ve para üstü vermeyi gerektirecek şekilde tam para ile binmeyen yolcuları otobüse kabul edilmeme konusunda otorite sahibi olduklarını belirtirler. Otobüse binmeyi "başaranlar" ise seyahat süresince şoförlerin gözetimi altındadır. Şoförler özellikle otobüs durakları ve trafik ışıklarında olmak üzere, dikiz aynasından ya da arkasını dönüp bakmak suretiyle yolcuların davranışlarını denetler ve kontrol ederler. Sözlü komutlarla yolcuları yönlendiren şoförler, otobüsten inmeyeceği halde iniş kapısına yakın duranları ikaz etme, yaşlıları boş koltuklara yönlendirme ya da yüksek sesle konuşanları uyarma gibi bir takım düzenleyici faaliyetlerde bulunurlar. Sürücülerin kendilerini izlediğinin farkında olan yolcular da hareketlerini buna göre düzenleyerek, yere çöp atma gibi kurallara uymayan davranışları, şoförün yol ile meşgul oldukları zamanlarda gerçekleştirirler. Otobüs içerisindeki kontrol sadece şoförlerle de sınırlı değildir. Otobüs içerisindeki kameralar ve otobüs ortamı boyunca dağılmış olan uyarılar yolculara kaçınmaları ve uymaları gereken davranışları salık verir.

Ankara'daki otobüslerde yapılan gözlemler de göstermiştir ki otobüs sürücüleri ve yakın zamanda işlerine son verilen muavinler otobüslerdeki sosyal kontrolün sağlanmasında oldukça aktif ve etkilidirler. Otobüse bazen ücreti olmayan yolcuları alabildikleri gibi, bazen de kart bakiyesi bitmiş kişilerin otobüs içerisindeki yolculardan kart temin etmelerine izin verirler. Fakat bunun yanında, daha önce de belirtildiği gibi, dış görünüşünü beğenmedikleri kişileri otobüse almayabilirler. Özel halk otobüsleri ve belediye otobüslerinin sürücülerinin davranışları da birbirinden ayrışmaktadır. Özel halk otobüslerinde, muavinlerin çalışmaya devam ettiği zamanlarda, hem şoförü hem de yolcuları yönlendiren kişi muavinlerdi. Muavinler şoförleri otobüse yetişmeye ya da binmeye çalışan yolcular konusunda yönlendirdikleri gibi; yolcuları da arka taraflara ilerlemeleri, boşlukları doldurmaları konusunda sürekli uyarmakta, yolcular arası tartışmaları sonlandırmaya çalışmakta ya da karar mercii gibi davranarak kimin haklı kimin haksız olduğu konusunda söz söyleyerek 
müdahalede bulunmaktaydılar. Dahası ücreti alıp, bilet kesen muavinler denetim olacağı zamanlar dişında yolculara bilet vermekten imtina ederken; serbest kartla otobüse binen yaşlılara olumsuz davranışlar sergileyerek, bu kişilere bir anlamda sembolik şiddet uygulamakta, otobüse binmelerine engel olmak istemekteydiler. Muavinlerin özel halk otobüslerindeki işlerine son verilmesi şoförlerin bu görevi de üstlenmelerine neden olmuş ve belediye otobüslerinde rastlanmayacak şekilde bu şoförlerin, özellikle duraklarda olmak üzere, ayağa kalkarak otobüs içerisindeki yolcuları yönlendirmeye çalıştıkları görülmüştür. Dahası ücretle otobüse binmek belli bir süre sonra yasaklanmış olmasına rağmen, özel halk otobüslerindeki şoförlerin yolculardan ücret alarak binmelerine izin vermeye devam etmeleri de gözlenmiştir. Kısacası özel halk otobüsleri sürücüleri, sürekli olarak kuralları çiğneyerek, yontarak gelirlerini artırmaya çalışmakta ve bunun yanında otobüsü aşırı hızlı sürmek, kırmızı 1ş1kta geçmek, otobüs sürerken telefonlarıyla uğraşmak gibi başka kuralsız eylemlerde de bulunarak yolcularla sürekli bir şekilde münakaşa etmektedirler. Belediye otobüslerinin şoförleri ise daha yüksek oranda kurallara uymakta, her ne kadar yolcuları gözlemleyip, yönlendirmeye çalışsalar da bu konuda israrcı olmayarak yolcularla daha az tartışma içine girmekte ve sosyal kontrolü sağlama işlevlerini sürdürmektedirler.

Connor ve Tewksbury'e göre (2012, s.8-9) sürücüler ve otobüs ortam1 sosyal kontrolü temsil etmesine ve kolaylaştırmasına rağmen, yolcuların kendileri, otobüs ortamındaki sosyal kontrolün yaygın doğası nedeniyle büyük ölçüde birbirlerine sosyal kontrol uygulamazlar. Otobüse binen çoğu kişi, uyuma, okuma veya pencereden dışarı bakma aktivitelerine yoğun bir şekilde dâhil olur. Diğerleri seyahat sürelerini cep telefonları ve müzik çalarlar gibi teknolojik cihazlarla uğraşarak geçirmektedir. Bu şekilde, yolcular genellikle başkalarının davranışlarından habersizdir. Mevcut çalı̧̧ma kapsamında yapılan gözlemler ise bunun tersini göstermektedir. Yolcular her ne kadar kendileri bir takım aktivitelerle meşgul olsalar da çevrelerinin farkındadır. Özellikle yaşlı ve orta yaşlı yolcular arasından olmak üzere, yolcular da birbirlerinin davranışlarına müdahalede bulunurlar. Gençler daha çok cıklama, homurdanma veya ters ters bakma gibi sözel olmayan davranışlarla tepkilerini gösterirken; yaşlı ve orta yaşlı kişiler sözsüz iletişimsel beceriler sergilemelerinin yanında 
daha çok sözel olarak etraflarını kuralsız ya da rahatsız edici davranışlar hakkında uyarırlar.

Balan'ın (2011, s.1883) gözlemleri de toplu taşımada yolcuların kişisel alanın ihlali ya da herhangi bir rahatsızlık durumunda bazı sözsüz iletişim teknikleri geliştirdikleri yönündedir. Kişiler bu tip durumların varl1ğında öncelikle rahatsız olunan kişinin görüşünden kaçınmaya çalışmışlar ya da çeşitli sinirlilik jestleri (ritmik bir şekilde nefes almak, of demek gibi) göstermişlerdir. Bunun yanında, daha çok gençler arasında gözlemlendiği gibi, yolcular diğer yolculardan kendilerini iki şekilde soyutlamışlardır. İlki mekânsal olarak daha boş yerlerde konumlanarak, ikincisi sosyal olarak etkileşimden kaçınmak için telefon, kitap gibi objelerle meşgul olarak.

Balan gibi, otobüs içinde araştırma yürüten Nichols, Berry ve Kalogrides "Hop on the Bus: Driving Stratification Concepts Home" (Otobüse Binmek: Tabakalaşma Kavramlarını Eve Sürmek) başlıklı çalışmalarında, Amerika Birleşik Devletleri'ndeki eşitsizlik ve yoksulluğu ortaya koymak için, öğrencilerinin toplu taşımada yaptıkları gözlemlerden yararlanmışlardır. Öğrenciler üniversiteden bir alışveriş merkezine giden yalnızca 8 kilometrelik bir yolda birbirinden oldukça farklı ekonomik gerçekliğe sahip insanlarla karşılaşmışlardır. Otobüslerde yapılan gözlemler sonucunda öğrenciler kendi çevrelerinin dişındaki toplumsal yapıyı sorgulamaya başlamış, yapısal faktörlerin bireysel deneyimlere nasıl etki ettiğini görmüş ve yoksul insanların karşılaştıkları zorlukları daha iyi anlamıştır (Nichols vd., 2004). Bu çalışmanın da gösterdiği gibi, otobüsler farklı kesimlerden insanların karşılaşmalarına, birbirlerini gözlemlemelerine ve bazen de etkileşim içine girmelerine neden olmaktadır.

Liz Grauerholz ve Marc Settembrino ise "Public Transportation and Visual Sociology to Make It Real" (Toplu Ulaşım ve Onu Hayata Geçiren Görsel Sosyoloji) adlı çalışmalarında, kendilerinin de ifade ettiği gibi "Hop on the Bus: Driving Stratification Concepts Home" makalesinin bir uyarlamasını gerçekleştirmişlerdir. Nichols ve diğerlerinin çalışmasına ek olarak, bu çalışmada öğrenciler hedef noktalarına (şehir merkezi) vardıklarında bulundukları yeri fotoğraflamışlardır. Grauerholz ve Settembrino bu pratik aracılığıyla, öğrencilerin çevreleri ve diğer insanlarla daha yakından bir iletişime gireceklerini ve bu sembolik egzersizle öğrencilerin sosyal eşitsizlik ve gelir eşitsizliğine dair sosyolojik bir anlayış 
ve farkındalık geliştireceklerini düşünmüşler, ancak öğrenciler fotoğraf çekmeye otobüs içerisinde gözlem yapmak kadar önem vermemişlerdir (Grauerholz ve Settembrino, 2016, s.200-209).

\section{Toplu Taşımanın Toplumsal Cinsiyetli Hali}

Liz Grauerholz ve Marc Settembrino'nun söz konusu çalışmasının sunduğu önemli bilgilerden biri, öğrencilerin güvenliğe dair sorunları olmuştur. Özellikle kadın öğrenciler kendilerini güvende hissetmediklerini ve taciz edildiklerini hissetmişlerdir. Bir öğrenci bunu şöyle dile getirmiştir: "Durakta taciz edildiğimi hissettim, erkekler size hiç bir kadın görmemiş gibi bakıyorlar ve doğrudan gözlerine bakarken bile size bakıyorlar." Bu sorunları yaşayan öğrenciler için kendilerini daha güvende hissetmeleri için ödevi bir başka arkadaşlarıyla yapmalarına izin verilmiş, bunun yanında gündüz saatlerinde otobüse binmek, tedirgin hissettikleri durumlarda otobüs sürücüsüne yakın oturmak gibi bir takım önerilerde de bulunulmuştur. Seçilen rota nispeten güvenli bir geçmiş ve itibara sahip olsa da kadın öğrenciler bu sorunlarla karşılaşırken, erkek öğrencilerin taciz veya güvenlik endişesine dair deneyimlerinin olmaması, yazarların da belirttiği gibi, otobüse binme deneyiminin de oldukça cinsiyetli olduğunu göstermiştir (Grauerholz ve Settembrino, 2016, s.210). Erendüz Atasü'nün “Çocukluğumu İstiyorum, Çocukluğumu Verin Bana" adlı öyküsünde yer alan aşağıdaki pasaj, hem bu durumun evrenselliğine, hem de tacize maruz kalan kadınların hissettiklerine ve bu durumla baş etmek için geliştirdikleri stratejilere bir örnek olabilir:

Hayat benden önce davrand1 ve kalabalık bir otobüste aramızdaki ağda ilk deliği o açtı, hoyrat elleriyle. Annemle babam beni yabancı dil öğretimi yapan özel bir okula yazdırmıştı. Bizim mahallede oturan birkaç kızla birlikte okula "öğrenci otobüsüyle" gidip geliyordum. Büyük sınıftan erkek grupları da vardı. Ve otobüs çok kalabalıktı. Önceleri ne yaptıklarını bile anlayamadım. Birileri ellerini paltomdan içeri sokmuş, bir yerlerime dokunuyordu. Hiç anımsamıyorum neremi tuttuklarını. Çok, hem de çok korktuğumu anımsıyorum. Niyeyse anneme babama söyleyememiştim bu olayı. Utanmış miydım, bilmiyorum; suçlanmış mıdım, anımsamıyorum. Ama oğlanın hain hain bakan sarı gözleri belleğime işlemiş; o gözleri hiç unutamamıştım. Tek bildiğim çok kork- 
tuğumdu... Dipsiz, karanlık bir kuyuya düşüyordum düşlerimde. Geceleri annem ve babamla yatmaya başlamıştım. Sonunda anlattım onlara. Diğer kızlar da ailelerine yakınmış olmalılar ki, okul yönetimi olaya el koydu. Otobüse polis binmeye başladı. Tek bir polis, iğne at yere düşmez otobüste ne yapsın?.. Olay sürdü gitti. Biz kızlar kendi başımıza öylece kalakalmıştık... Annemizin babamızın bize yardım etmesi olanaksızdı... Eve dönüşlerde okul taşıtını kullanmaktan vazgeçtik; belediye otobüsünü denemeye başladık. Ne olsa belediyenin otobüsü daha tenhaydı. Sonra orada yaşlı başlı insanlar vardı. Küçük kızların rahatsız edilmesine herhalde göz yummazlardı. Durmuş oturmuş kimselerden hayır beklememeyi tez öğrendik. Başımıza gelenler karşısında kör ve sağır kesiliyorlardı. Belediye taşıtı öğrenci taşıtından farksızdı. Otobüse özellikle okul durağından binen, bu işin meraklısı yaşlı adamlar vardı. Bir kez sahanlıkta duruyordum, tek başımaydım, otobüs bayağı boştu; o adamlardan biri yanıma yaklaştı, kalçama sert bir şey dayadı. Tuhaf tuhaf soluyordu. Adamın hastalandığını sandım. O kadar küçük ve bilgisizdim ki, kalçama dayanan sert şeyin adamın penisi olduğunu yıllar sonra anladım. Korkudan taşlaşmıştım, ne olduğunu anlamıyordum, sanki sesimi yitirmiştim, soluğum bile çıkmıyordu. Adamın ne yaptığını görenler vardı ama kimse aldırmiyordu. Zamanla ne anadan ne babadan, ne okul yönetiminden, ne polisten, ne yolculardan hayır geleceğini öğrenmiştik. Bu oğlanlar ve adamlar her yerdeydiler ve onlarla kendimiz başa çıkmak zorundaydık. Otobüslere toplu halde binmeyi, birbirimizden ayrılmamayı, erkeklerin bakışlarından niyetlerini sezip uzaklaşmayı, otobüsün göreli tenha kısımlarında durup, itiş kakışın içine girmemeyi öğrendik. Ve tam utanmamayı, şirretleşmeyi öğreniyorduk ki, bizim hatta dolmuşlar işlemeye başladı, otobüslere veda ettik (Atasü, 1983/2011, s.152-153).

Hamilton, Jenkins, Hodgson ve Turner'ın (2005, s.iii-iv) Promoting Gender Equality in Transport (Ulaşımda Toplumsal Cinsiyet Eşitliğini Teşvik Etmek) adlı çalışmaları da kadınların erkeklerden farklılaşan ulaşım pratikleri üzerinde durmuş ve kadınların farklı zamanlarda, farklı yollarla, farklı sürelerde ve farklı yerlere seyahat ettiklerini göstermiştir. Ulaşım sisteminin erkekler tarafından erkekler için inşa edildiğini söyleyen yazarlar, ulaşımın sosyal boyutuna son yıllarda daha çok önem verilse de ulaşımın toplumsal cinsiyete göre farklılaşan yönlerine, kadınların 
farklı deneyimlerine hala yeterince önem verilmediğini belirtmektedirler. Örneğin istihdam ve ücret politikaları erkeklerin iş yaşamında öncelikli olarak yer almalarına yol açmakta, bununla bağlantılı olarak ve/veya başka değişkenlerin de etkisiyle kadınlar çocuk, hasta bakımı gibi bazı ev içi sorumluluklar ile alışveriş gibi evin bazı birincil sorumluluklarını üstlenmek zorunda kalmaktadırlar. Bu durum kadınların toplu taşıma araçlarını mesai saatleri dışında kullanmalarına neden olmakta, fakat mesai saatleri dışında ulaşım araçlarının azalması kadınların ulaşım araçlarına ulaşımında mağduriyete neden olmaktadır. Bunun yanında daha önce de bahsedildiği gibi, hem ulaşım araçları içerisinde hem de dışında kadınlar kendilerini tacize karşı korumak için geç saatlerde yolculuk etmekten kaçınmaktadırlar.

Ankara'da toplumsal cinsiyete dayalı ulaşım politikalarını inceleyen ve bu bağlamda 28 kadınla görüşme gerçekleştiren Kalfa, Aytekin ve Dinç'in (2009, s.226-229) çalışmaları da ulaşım açısından kadınların yaşadıkları zorlukları ortaya koymaktadır. Bu çalışmada görüşme yapılan kadınlar Ankaray ve Metro'dan hızlılık emniyet ve konfor açısından memnun olduklarını, ancak otobüslerden memnun olmadıklarını dile getirmişlerdir. Bu durumu etkileyen önemli unsurlardan biri kadınların yaya olarak şehirdeki hareketliliklerini de etkiyen aydınlatma problemidir. Aydınlatmanın Metro ve Ankaray'da yeterli olması güven hissini artırırken; otobüslerde, sokaklarda köprü altı ve alt geçitlerdeki yetersizliği kadınların güvenlikleri açısından endişelenmelerine neden olmakta ve bu durum da kadınların mobilite oranlarını düşürmektedir. Bunun yanında Clifton ve Livi'nin (2005, s.83) yürüme aktivitesinde cinsiyet farklılıkları üzerine yürüttükleri çalışma da göstermiştir ki, kadınlar güvenlik endişeleri nedeniyle yalnız yürümektense aile bireyleri ya da arkadaşlarıyla yürümeyi tercih etmektedirler. Öte yandan kadınlar bir sosyal aktivite olarak yürüyüşü tercih ettikleri gibi, yürüyüş ev içi sorumluluklarının bir uzantısı olarak çocukları okulda götürüp getirme ya da yaşlılara yürüyüşlerinde eşlik etme gibi sorumlulukların bir parçasıdir.

Kadınların güvenlik ve taciz endişesiyle bağlantılı olarak toplu taşıma araçlarında en çok rahatsız oldukları durum ise aşırı kalabalık ve fiziksel temastır. Mesai saatlerinde toplu taşıma araçlarının mevcut nüfusun ihtiyaçlarına karşılık vermemesi, diğer zaman dilimlerinde de az sayıda 
ulaşım aracının hizmete sunulması aşırı kalabalıklara neden olmakta bu durum da kadınların tacize uğrama risk ve kaygılarını artırmaktadır. Kadınların ulaşım araçlarına erişim ve kullanma sıklı̆̆ını etkileyen diğer faktörler ise maddi olanaklar/olanaksızlıklar ve otobüs güzergâhlarının merkez çevre ilkesi doğrultusunda, yani çalışma yaşamına göre ayarlanması nedeniyle, mahalle odaklı ulaşım hizmetlerinin sunulmaması ve bunun birden fazla araç kullanımı gerektirmesi, yani maddi külfeti artırmasıdır. Kalfa ve diğerlerinin çalışmasının ortaya koyduğu bir diğer sonuç da görüşülen kadınların ehliyet sahibi olma ve özel araç sahipliği oranının oldukça düşük olmasıdır. 28 kadından sadece 6'sının ehliyetinin olduğu ve yalnızca 3 kişinin aktif olarak araç kullandığ saptanmıştır. Bu durumun başlıca nedenleri ise, maddi imkansızlıklar ile kadının hane içinde ehliyet ve araç sahipliğinin ikinci planda görülmesidir (Kalfa vd., 2009, s.228-231). Önceki makalelerde de görüldüğü gibi, ulaşım alanı erkekler için erkekler tarafından inşa edilmekte ve erkekler bu alandaki üstünlüklerini ehliyet ve araç sahipliği konusunda da sürdürmektedir.

\section{Tartışma ve Sonuç}

Ulaşım sosyolojisi çok katmanlı, çok bileşenli ve gündelik yaşamın önemli bir parçası olması bakımından oldukça değerli ve verimli bir alandır. Birbiriyle örtüşen birkaç çalışma dışında bu alandaki konuların çeşitliliği de bunun kanıtıdır. Ulaşım sosyolojisi açısından odaklanılan coğrafya, bölge, araç, hat ve kapsama göre farklı ve çeşitli verilere ulaş1labileceği gibi, çalışmaların değişen perspektifleri de bu zenginliğe katkıda bulunabilir. Nitekim bu makale kapsamındaki metinler de bunu açıkça göstermiştir. Çalışma konularına baktığımızda bu makaleler yolcuların psikolojisine, yolcular arası ilişkilere, yolcu ve sürücülerin performanslarına, sosyal kontrole, araç içi aktivitelere, ulaşım aracının yapisının insanlar üzerindeki etkisine, ulaşım pratiklerinin gündelik yaşamdaki yansımalarına, toplu taşımanın eşitsizlik ve yoksullukla bağına, ulaşımın toplumsal cinsiyetli yapısına veya birden çok noktaya parmak basmıştır. Makalelerin geneline bakıldığında, Kalfa, Aytekin ve Dinç'in makaleleri dışında, en göze çarpan eksikliklerden birisi yolcuların ve şoförlerin sesinin yokluğudur. Bu eksiklik önemlidir çünkü toplu taş1mayı sosyolojik bir alan veya analiz konusu yapan eksen insan/yolcu 
faktörüdür. Bunun yanında bu makalede aktarılan birkaç çalışma öğrencilerle ya da birkaç kişinin işbirliği ile yürütülmüş olsa da yine de bu gözlemler kısıtlı gibi gözükmektedir. Bu durumun doğruluğu ya da yanlışlığ 1 ancak katılımlı gözlem ile derinlemesine görüşmelerin sentezlendiği çalışmalarla daha net olarak anlaşılabilir.

Toplu ulaşım araçlarını kullanan yolcular aralarında bir bağ olmayan, belli bir amaç doğrultusunda aynı araçta yer alan kişiler olsa da, aynı mekânı kullanmanın bir sonucu olarak ister istemez bir takım iletişim ve etkileşim faaliyetlerinde bulunur; mekân içi konfor ya da korunma gibi ihtiyaçlar nedeniyle bir takım taktikler geliştirirler. Bu taktikler otobüs içinde konumlanacak yerin belirlenmesi için de, otobüs içerisinde oyalanmayı sağlayacak aktivitelerin gerçekleştirilmesi için de; yaşlı biriyle sohbet etmekten kaçınmak için de, yeni biriyle tanışmak için de uygulanabilir. Elbette toplu ulaşım aracında geçirilecek yolculuk süresi tüm bu taktikleri gereksiz kılabileceği gibi, yeni bir takım davranışlar setine de ihtiyaç hissettirebilir. Ulaşım araçlarında geçirilen zaman ve ulaşım araçlarının koşulları kişilerin ruh sağlıklarında ya da gündelik yaşamlarında deformasyonlara neden olabilir. Bunun yanında otobüs içerisinde karşılaşılabilecek şiddet ya da taciz gibi mevzular da kişilerin yaşamlarında iz bırakan travmatik deneyimlere dönüşebilir. Bu nedenle toplu ulaşım hem kent planlayıcıları hem de yerel yönetimlerin yolcuların ihtiyaç ve taleplerini dikkate alarak düzenlemeleri gereken, genel yolcu kategorilerine olduğu kadar dezavantajlı kişilerin durumlarını da gözettikleri bir alan olmalıdır

Her bir ulaşım aracının içinde gerçekleştirilen farklı pratikler ve ritüeller vardır ve bunlar zaman içinde değişime uğrar. Örneğin bundan on ya da yirmi yıl önce şehiriçi tren vagonlarında seyyar satıcılar gezer, belirli satış teknikleriyle pazarlama yaparlardı. Daha geçen yıla kadar halk otobüslerinde muavinler otobüs içerisindeki düzenin ve kontrolün sağlanmasında en göze çarpan ve belki de en şikâyet edilen unsurdu. Dolmuşlarda ücret arkadan öne doğru uzatılır, bu yolla yoğun bir iletişim ve etkileşim ortamı oluşurdu. Günümüzde büyük oranda ortadan kalkan bu pratik ve alışkanlıklar, yerini yeni alışkanlıklar ve kurallara bırakmakta, eskiden olağan olan, artık yadırganır hale gelmektedir. Bu değişimler büyük oranda yolculuğun daha konforlu bir biçim kazanmasını -gürültünün ve kargaşanın azalması gibi- sağlasa da, özellikle bü- 
yük şehirlerde olmak üzere, toplumsal yaşamdaki bireyselleşmenin de bir göstergesidir. Keza bu bireyselleşme ve yabancılaşma toplu ulaşım araçlarındaki iletişim ve etkileşimde de kendini hissettirmekte, daha genç bireyler yabancı birinden gelen sohbet isteğini kuşku ve isteksizlikle karşılarken; orta yaş üstü kişiler genellikle daha rahat bir şekilde iletişim kurmaktadır. Toplumsal konularda görüş bildirme her geçen gün azalmaktadır. Tüm bu değişimler toplumun genel yapısında meydana gelen dönüşümlerinin mikro bir alandaki yansımasıdır ve -iletişim sosyolojisi ve siyaset bilimi gibi- pek çok farklı disiplinden araştırmacının alana katkılarıyla daha net bir resmin ortaya çıkması sağlanabilir. 
EXTENDED ABSTRACT

\title{
The Main Dimensions of Public Transport Sociology: Literature Review and Field Observations
}

\author{
Ayşe Mirza Girgin - Himmet Hülür \\ Hacı Bayram Veli Univesity
}

Sociology of transportation is a wide and ambiguous concept. Studies produced in this field generally focus on the structure and characteristics of transportation, vehicles of transportation, urban transportation policies, problems, and solutions in the field of transportation. Since the research on transportation is generally carried out by the researchers from the faculties of architecture and the departments of city and regional planning such studies are limited to these disciplines. The purpose of this article is to underline the importance of this field by providing a review of the relatively few studies on the human relations aspect of the area of public transport and by providing a literature review on studies that address the elements that shape human behavior and interaction in public transport. Hence the vehicle of public transport is one of the important public spheres where many people come together and interact, realizes verbal and non-verbal communicative action, and which involves its own rituals and habits. Though the important place of public transportation in human life was emphasized by the early studies in the field of sociology of public transportation that begun in 1960's, these studies drew attention to the fact that there were not adequate research and sociological theory. These studies also questioned the reasons of that situation. In the forthcoming years although the subjects of study have been differentiated and specialized, the initial studies were more extensive and therefore the studies we descriptively examined in this article are discussed in the chronological order and these early studies are given a greater place then the late studies. In addition, even though the literature in the field of public transportation have been extended in time, the contemporary studies are still underlining the gaps in this field. One of the most important reasons for this is the fact that sociology of transportation is rather a rich area of study and still requires studies that are rich 
in content and comprehensive. Beside there are very few original studies in Turkish, there are considerable, the World literature has not been translated into Turkish more than a little. Hence in this article we try to draw a frame for the sociology of transportation, and we blend participant observation with the relevant literature in this field. Empirical data has been obtained through the participant observation that has been carried out in Ankara in the municipal and private-public buses in a period of more than three years.

It is debatable whether public transportation vehicles are private, public or semi-public spaces, but we cannot deny the fact that they offer an important environment of encounter, communication and interaction for people who do not know each other. As a result of the observations made in this regard, it has been seen that passengers using public transportation vehicles engage in communication and interaction although they don't know each other and they are in the same vehicle for a certain purpose and develop a number of tactics due to their needs of comfort and protection. These tactics can be applied to decide on the spot to sit in the bus, to engage in activities that will allow you to linger in the bus, or to avoid possible disturbance and harassment from someone who wants to chat, or to meet someone new. Of course, the journey time spent in a public transport vehicle may make all these tactics unnecessary, as well as make you feel the need for a new set of behaviors. In addition, different age groups or women may need different strategies. For example, elderly people may try to sit at the front of the bus because they feel inadequate in terms of their physical capacity due to health problems, or women may also need more careful positioning to protect themselves from possible incidents of harassment. On the other hand, passengers can sometimes make plans for quite practical reasons, such as avoiding sunlight, watching outside, or being close to the door for getting off swiftly.

Another issue that creates, affects or is interrupted by interpersonal interaction in public transportation is road activities. Passengers can engage in activities such as listening to music, playing with their phones, reading a book, watching the outside or inside a transport vehicle, chatting or sleeping during their trip. The fact that public transportation vehicles are closed environments where passengers remain motionless may 
limit the activities to be done during the journey. In addition, indoor factors such as the vehicle being crowded or noisy, and personal factors such as the ability of people to use communication tools also shape road activities. A passenger who is bothered by his eyes may try to chat with someone listening to music and interfere with that person's activity because he only has the option to watch outside or chat or someone who listens to loud music may disturb a person who is reading a book. These disturbances can lead to communicative or gestural activities such as verbal warnings or symbolic interactions such as eye rolling and grunting.

Among the main factors responsible for the above problems are the use of public transportation mostly due to necessity in places where income inequality is high, and the fact that it brings individuals together with a bunch of people and groups who were not in their personal environment before. In such environments, where only one person does not care about interpersonal distances, communication disruptions are inevitable. Therefore, the combination of problems caused by individuals with the coercive structural factors of public transportation can sometimes lead to problems that can also give way to different forms of violence. Under the influence of all these factors, the time spent in transport and the conditions of the means of transport can cause deformations in the mental health of people or in their everyday life. Therefore, public transport must be an area that both urban planners and local governments should regulate considering the needs and demands of passengers as well as the general categories of passengers and the situation of disadvantaged people should also be taken into account.

\section{Kaynakça/References}

Atasü, E. (2011). Çocukluğumu istiyorum, çocukluğumu verin bana. Dullara Yas Yakışır. İstanbul: Everest Yayınları, s.139-169.

Balan, A. (2011). A study of symbolic relations in public transport. Lex ET Scientia International Journal, XVIII(1), 1878-1884.

Bateman, J. R. ve Brown, J. W. (1968). Urban planning, transport and human behavioral science. Guidlines for New Systems of Urban Transportation II. Barton-Aschman Associates, 1-43. 
Connor, D. P. ve Tewksbury, R. (2012). Social control on public buses. Journal of Theoretical and Philosophical Criminology, 4(1), 1-13.

Davis, M. ve Levine, S. (1967). Toward a Sociology of Public Transit. Social Problems. Society for the Study of Social Problems, 15(1), 84-91.

Goffman, E. (2016). Kamusal alanda ilişkiler: Toplum yaşamın mikro ilişkileri. (M. F. Karakaya, Çev.). Ankara: Herektik Basın Yayın. (Orijinal eserin yayın tarihi 1971).

Grauerholz, L. ve Settembrino, M. (2016). Teaching inequalities: Using public transportation and visual sociology to make it real. American Sociological Association, 44(3), 200-211.

Hamilton, K., Jenkins, L., Hodgson, F. and Turner, J. (2005). Promoting gender equality in transport. Equal Opportunities Commission. 1 Kasım 2020 tarihinde chromeextension://oemmndcbldboiebfnladdacbdfmadadm/https://www.ssatp.org/sites/ssatp/ adresinden erişildi.

Kalfa, A., Aytekin, B. S. ve Dinç, Z. Ö. (2009). Kent içi ulaşımın cinsiyeti: Ankara örneği. A. Alkan (Der.). Cins Cins Mekan içinde (s.217-242). İstanbul: Varlik Yayınları.

Korte, C. ve Grant, R. (1980). Traffic Noise, environmental awareness and pedestrian behavior. Environment and Behavior, 12(3), 408-420. https://doi.org/10.1177/0013916580123006.

Lundberg, U. (1976). Urban commuting: Crowdedness and catecholamine excretion. Journal of Human Stress, 2(3), 26-32. DOI: 10.1080/0097840X.1976.9936067.

Nichols, L., Berry, J. and Kalogrides, D. (2004). Hop on the bus: Driving stratification concepts home. Teaching Sociology, 36(3), 213-221. https://doi.org/10.1177/0092055X0403200207.

Rosenbloom, S. (2006). Understanding women's and men's travel patterns. Research on Women's Issues in Transportation, 1, 8-28.

Yago, G. (1983). The sociology of transportation. Annual Review of Sociology, 9, 171-190. https://doi.org/10.1146/annurev.so.09.080183.001131.

\section{Kaynakça Bilgisi/Citation Information}

Mirza Girgin, A. ve Hülür, H. (2021). Toplu ulaşım sosyolojisinin temel boyutları: literatür incelemesi ve alan gözlemleri. OPUSUluslararası Toplum Araştırmaları Dergisi, 18(44), 8389-8419. DOI:10.26466//opus.933443. 